\title{
Sessile oak (Quercus petraea (Mattuschka) Liebl.) trees variability according to an analysis of multispectral images taken from UAV - first results
}

\author{
Krzysztof Będkowski, Krzysztof Stereńczak
}

Department of Forest Management, Geomatics and Economics

Warsaw University of Life Sciences - SGGW

Nowoursynowska 159, 02-766 Warsaw, Poland

e-mail: krzysztof.bedkowski@wl.sggw.pl

\begin{abstract}
The paper presents first results of the use of multispectral aerial images to identify the outum phenophases of sessile oak. Observed phenophases are represented with three leaf colors - green, yellow and brown. Color composition of images in three spectral bands: blue, green and red, taken by digital non metric Sigma DP2 cameras, which were carried by Unmanned Aerial Vehicle (UAV) were used. Pictures were taken on 17 October 2011. Two observers made visual crowns classification of 556 oak trees into three groups: green, yellow and brown, on the basis of the dominant color of the leafs. It was found that among observers there is a large compliance in classification (79.7\%). Additionally, observations of the spring growth of leafs on 54 trees crowns images recorded from seven positions were evaluated. Although the results may indicate the existence of certain trends, the clear relationship between autumn and spring phases of trees growing can not be noted now (due to small number of sample and short time of observations). The use of UAV to monitor the length of the individual tree growing season has been confirmed.
\end{abstract}

Key words: phenology, sessile oak, Quercus petraea, UAV

\section{Introduction}

Sessile oak is one of three native oak species, quite often seen in Polish forests. In Poland, sessile oak reaches the northern boundary of occurrence. Sessile oak habitat is mostly sandy-loam soils, slightly acidic. Its forms single species stands, or a mixture with English oak (Quercus robur L.) or other deciduous species. Often, sessile oak is admixture species in Scots pine stands. For sessile oak, uneven development of the trees at the beginning and end of the growing season was notices. It is manifested mostly by unequal development of the leafs in spring and autumn. The differences in development, that can reach tens of days, are connected with different provenances, as well as with individual diversity and variability within a given population (Kadomatsu 1997). Although this phenome- non is the subject of numerous studies (also in many other species such as beech, ash, maple, alder, pine), it has not been fully explained until this time. The results of numerous studies indicate, for example, that the substrate of the observed differences within the population may be environmental and genetic factors (Kadomatsu 1997; Bobinac et al. 2012), micro differential of habitats characteristics (Oliveira et al. 1994), differences in the development of vascular (Sass-Klaassen 2011), temperature (Wesołowski \& Rowiński 2006), mechanic damages or floods (Morin et al. 2010), insect feeding (Waddell et al. 2001), trees height (Seiwa 1999). The order of leaf fall in autumn followed broadly the same order as bud burst in successive in next year (Crawley \& Akhteruzzaman 1988).

Observations in natural conditions, repeated in the same places over several years, can provide answers to 
the questions about extent of growing season variation between single oaks. This information can be used for stand or single tree biased growth models.

Lechowicz (1984) did not found any detailed phenological records for a single European forest. This has not changed apparently since then (Wesołowski \& Rowiński 2006 after Schwartz 1998 and Jenkins et al. 2002).

Unmanned aerial vehicles (UAV) are increasingly being used to obtain information wherever the use of aircraft is economically viable and meets the restrictions. Not cost-effective use of aircraft is i.e.: for small objects or in adverse weather conditions (too short periods of "photogrammetry" weather or too low cloud ceiling). In this case it may be reasonable to use unmanned devices, which can be equipped with a lightweight digital camera. Unmanned airborne vehicles have been used for military purposes long time ago, and for some time, have been offered by civil companies. Images obtained by them are used in urban area inventory (Gruen 2012), archaeological research (Eisenbeiss et al. 2005), analysis of agricultural crops and forests (Grenzdörffer et al. 2008, Clark et al. 2010). UAVs structurally resemble airplanes or helicopters. Digital cameras carried by UAV record images in RGB or infrared bands, often providing direct transmission to the ground operator. Flight control can be manual or fully automated - the UAV moves along the programmed route. There are "intelligent" designs, additionally equipped with laser scanners that recognize the terrain itself and, on this basis, achieving proper trajectory (Kumar 2012). In Poland, interest in flying unmanned vehicles has been seen for a long time (Jankowicz 2002a; 2002b; 2007). Currently, there are many systems of foreign origin operating in the country (Krolikowski 2011), but there are also ones developed as original Polish designs (Taxus SI 2010; Zmarz 2011).

Color aerial photographs, particularly infrared, are a well known tool for studies of high vegetation (Greer et al. 1990; Jaszczak 2000; Miścicki 1981, Stone \& Haywood 2006). It has been proved its ability to determine tree defoliation using canopy and discoloration resulting from the occurrence of the disease agents. Analysis focused on two coniferous species (spruce, fir) as well as beech and oak. In the initial period, the analysis methodology was based on the interpretation of the colors by the observers, and then developed digital processing methods and technologies have been developed for determining condition of the stands. However, while the use of aerial photographs to assess the health condition of the trees was studied in many publications, it is difficult to find analysis of phenological aspects with use of this technique. Few studies focus on the analysis of phenological events at the regional, national, or even continental scale (Muraoka \& Koizumi 2009). There are also few studies (Richardson et al. 2009) showing the use of remote sensing methods to assess the phenological variability within individual populations, such as the stand level.
This paper presents the preliminary results of study on the use of color images obtained by UAV to monitor the length of the growing season of sessile oak. Aerial orthomosaics were used for classification of sessile oak on three classes: tree crowns with leafs colored in green, yellow and brown. Distribution map of three previously separated classes was made. In this study, aerial photographs taken in the autumn were used as well as ground-based images.

\section{Materials and methods}

The study was carried out in the Głuchów Forest $\left(20^{\circ} 7^{\prime} \mathrm{E}\right.$, $\left.51^{\circ} 45^{\prime} \mathrm{N}\right)$, Forest Experimental Station in Rogów, which belongs to Warsaw University of Life Sciences. For this study sessile oak stands were selected, with a slight admixture of other deciduous and pine.

Aerial images were made using two non-metric digital cameras Sigma DP2. One of the cameras recorded blue, green and red spectral bands, second camera was rebuilt to record the near-infrared band (approx. 720-1200 nm). The possibility of recording the infrared reflectance was possible by removing the original IR filter. The filter previously was placed on the matrix elements of light-sensitive to prevent the infrared radiation be recorded, because matrix is sensitive to the radiation (Cheak 2004). At the same time, the camera was equipped with a filter (located on the lens), with visible light cut-off access. Details on how to rebuild the camera are given by Zmarz (2011) and Zmarz et al. (2012).

Camera was carried by unmanned aerial vehicle named AVI-1 (Taxus 2010), which was designed specifically for performing photogrammetric flights. The vehicle is powered by an electric motor, has wingspan of $3.5 \mathrm{~m}$, and its control is performed by autopilot. Capacity AVI-1 is sufficient to carry a standard digital camera or two compact digital cameras. In this project images from both cameras were recorded synchronously. They were used to prepare ortho-mosaics in RGB colors (Fig. 1).

Very important factors distinguish framework used in the presented study from typical photogrammetric tasks. The most important are: time of imagery acquisition (17 October - the end of the growing season) and light conditions. In the final stage of the growing season there are changes in the foliage, which show, among others, changes in color and foliage quantity. Autumn light conditions are much worst due to the low angle position of the sun over the horizon. It is also hard for good weather conditions. For these reasons typical aerial images are acquired very rarely during autumn. Unmanned aerial vehicles can also move at very low altitudes and can shoot well under the low ceiling of clouds. No direct sunlight is turning out to be a favorable circumstance, as the pictures are not very 
Figure 1. Natural color composite image with crowns being classified by one of image interpretators into three crown color groups (green, yellow, brown)

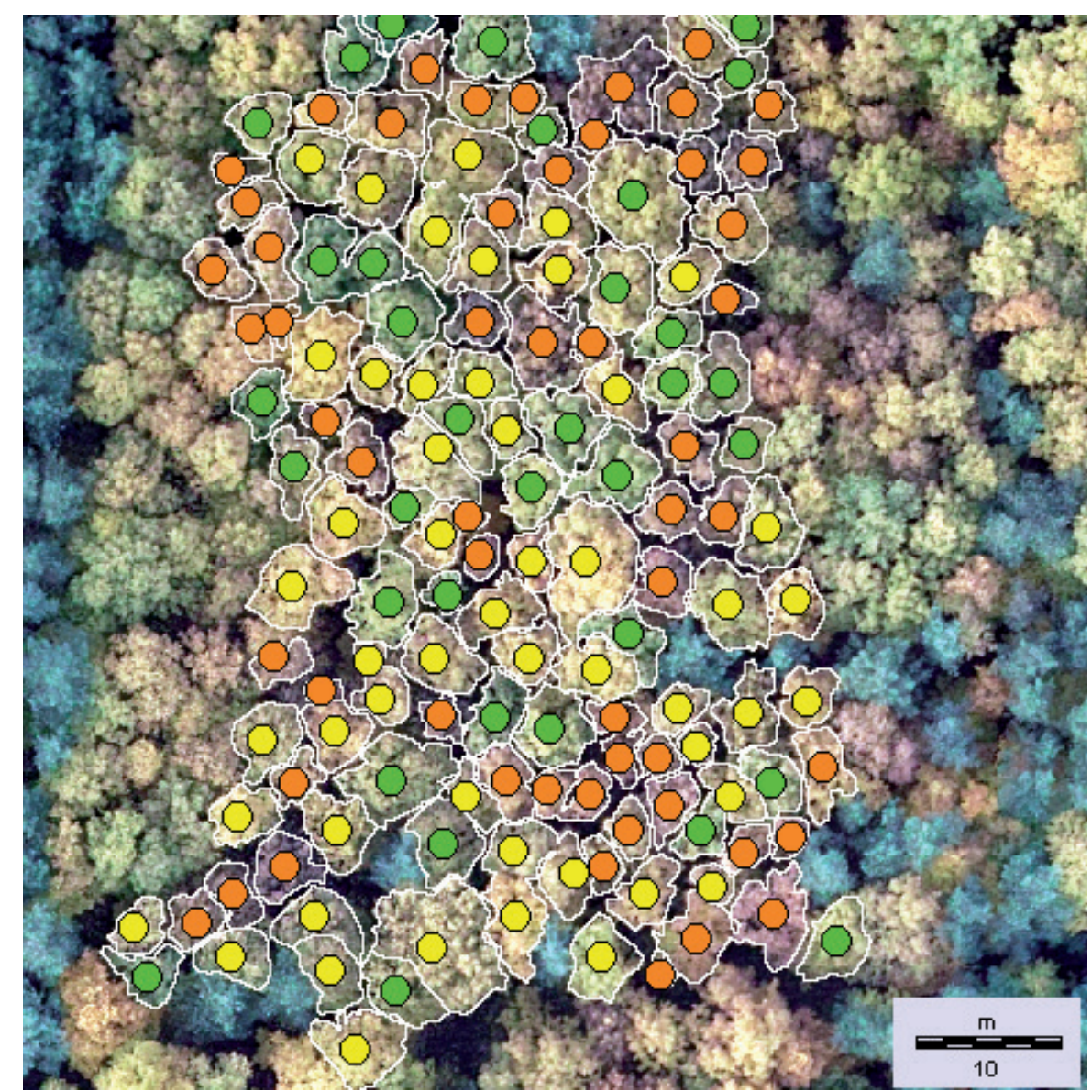

Figure 2. Comparison of classification results - unfilled crowns, shown only with their extends, are classified by two interpretators differently

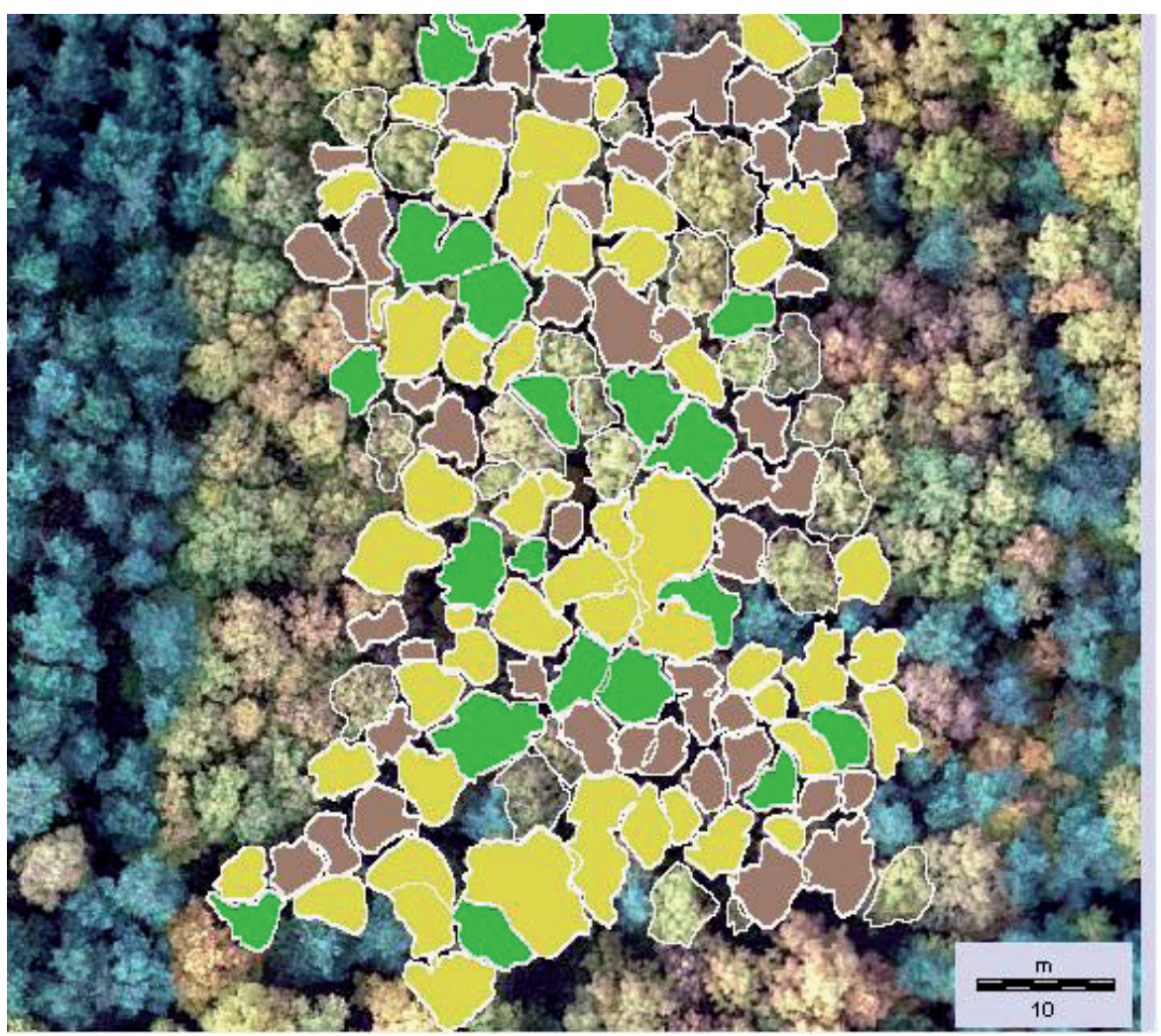


Table 1. Classification of oak crowns into three crown color groups ( 1 - green, 2 - yellow, 3 - brown $)$ - results of two interpreters

\begin{tabular}{|c|c|c|c|c|c|}
\hline & & \multicolumn{3}{|c|}{$\begin{array}{l}\text { The first observer } \\
\text { (number of crowns) }\end{array}$} & \multirow[t]{2}{*}{$\Sigma$} \\
\hline & & 1 - green & 2 - yellow & 3 - brown & \\
\hline \multirow{4}{*}{$\begin{array}{l}\text { The second observer } \\
\text { (number of crowns) }\end{array}$} & 1 - green & 111 & 29 & 2 & 142 \\
\hline & $2-$ yellow & 27 & 191 & 18 & 236 \\
\hline & 3 - brown & 1 & 36 & 141 & 178 \\
\hline & $\Sigma$ & 139 & 256 & 161 & 556 \\
\hline
\end{tabular}

Table 2. Concurrence of oak phenophases - autumn leaf colors (columns) and spring bud burst phases (rows) on 54 trees. Numbers shown are absolute and relative concurrence values

\begin{tabular}{|c|c|c|c|c|c|}
\hline & & \multicolumn{3}{|c|}{$\begin{array}{l}\text { The color of crowns observed on aerial images } \\
\text { taken in the autumn using UAV } \\
(17.10 .2011)\end{array}$} & \multirow[b]{2}{*}{$\Sigma$} \\
\hline & & 1 - green & 2 - yellow & $3-$ brown & \\
\hline \multirow{4}{*}{$\begin{array}{l}\text { The stage of leafs development } \\
\text { in the spring by terrestrial } \\
\text { image analysis (28.04.2012) }\end{array}$} & 1 - undeveloped buds & $7(0.13)$ & $7(0.13)$ & $10(0.19)$ & $24(0.45)$ \\
\hline & $\begin{array}{c}2 \text { - partially } \\
\text { developed buds }\end{array}$ & $4(0.07)$ & $5(0.09)$ & $7(0.13)$ & $16(0.29)$ \\
\hline & $\begin{array}{c}3-\text { developed visible } \\
\text { leafs }\end{array}$ & $3(0.06)$ & $2(0.04)$ & $9(0.16)$ & $14(0.26)$ \\
\hline & $\Sigma$ & $14(0.26)$ & $14(0.26)$ & $26(0.48)$ & $54(1.00)$ \\
\hline
\end{tabular}

contrasted - there are small tonal differences between the illuminated and shaded parts of the crowns of trees.

In the presented study an attempt was performed to assess the possibility of using the natural colors ortho-mosaics to identify single trees of sessile oak in different phonological phases. It was assumed, that these phases are distinguished by changes in crown color - from green, through yellow to brown. It was also decided to assess whether the trees are similarly recognized by the two observers. Spectral image analyzes for the possibility to distinguish between separate groups of tree crowns using digital methods were carried out. The last stage of the analysis was to compare the phenological events observed on aerial photographs in the autumn of 2011, with the observations made on the ground based photographs of tree crowns during spring 2012.

At the beginning, one observer has selected five sample plots, and pointed to ortho-mosaics ranges of 556 crowns of oaks (Fig. 1). The ranges were determined by digitizing crowns using the ArcGIS software. In the next stage, two observers, independently, divided all the crowns into three groups, according to their color. The first observer worked in the Idrisi Taiga software, while the second in the ArcGIS. Both have adopted the same methodology for the classification of tree crowns - green oak (group 1), followed by brown (group 3), and later with yellow (group 2) (Fig. 2). Comparison of classification results are presented in Table 1 and Figure 2.

Ground photos were taken with Sigma DP2 camera (same as used onboard of UAVs) in four dates: 6 and 28 April and 4 and 12 May (Fig. 3). The location of camera position was determined by comparing field distribution of trees with the content of aerial images. On the April 6, all oaks were in the phase of winter dormancy. Clear changes in the crowns emerged in late April and May. In this period, the relatively high air temperature resulted in rapid, distributed in a very short time period, development of leafs. Differences in leaf development can be seen very well basically just on photographs taken on 28 April. On 12 May all crowns looked very similar. Trees images captured on terrestrial photographs on 28 April (Fig. 4), were classified into three classes: 1 - undeveloped buds, 2 - partially developed buds, 3 - developed visible leafs. By comparison of airborne and terrestrial (Fig. 5) images of corresponding crowns, concurrence of autumn and spring phenological phases of development were defined (Tab. 2).

The aim of the used treatment was to obtain a response, whether and how oaks classified to one of 3 groups accord- 
Figure 3. Locations where terrestrial images of crowns were taken
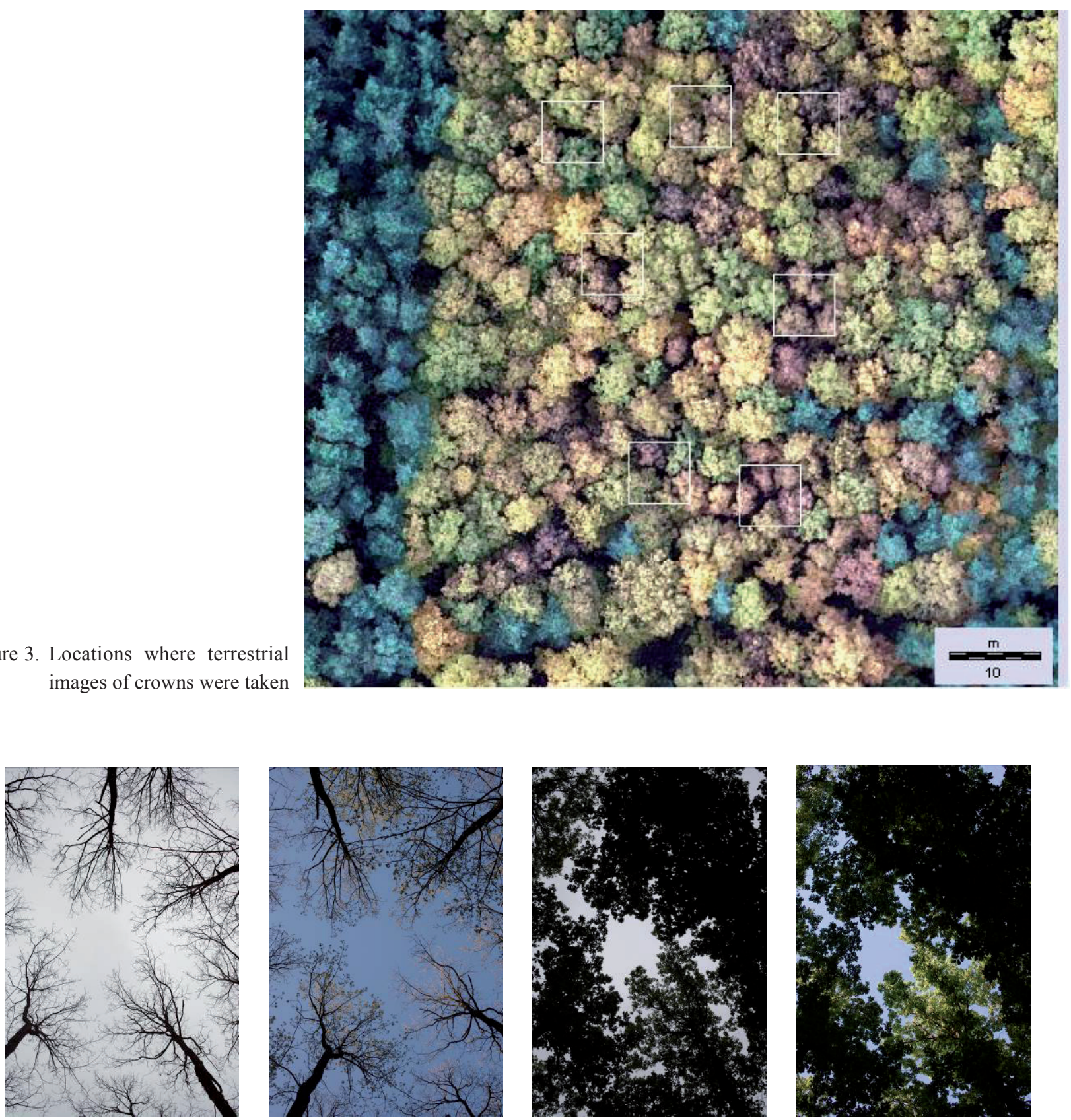

Figure 4. Oak bud burst and leaf development as on April 6, 28 and May 4, 12

ing to the color of crowns, differ spectrally; by means of digital image analysis. Image processing was carried out using Idrisi Taiga software (Idrisi 2009). The values of the average brightness were analyzed separately for each of the distinguished group of crowns, in four spectral channels. Original values were used, without pre-processing contrast. It may be noted, that the fourth channel (NIR) contains a relatively low value, which results sensitization of the relatively smaller image sensor in this area. In the calculations, all the image pixels those were within the crowns of trees were used. Figure 6 shows the mean values of brightness for nine classes, which arose from a comparison of the results of classification done by two observers. Figure 7 present values only for grades 1-1, 2-2 and 3-3, which means the trees classified by observers to the same groups. 

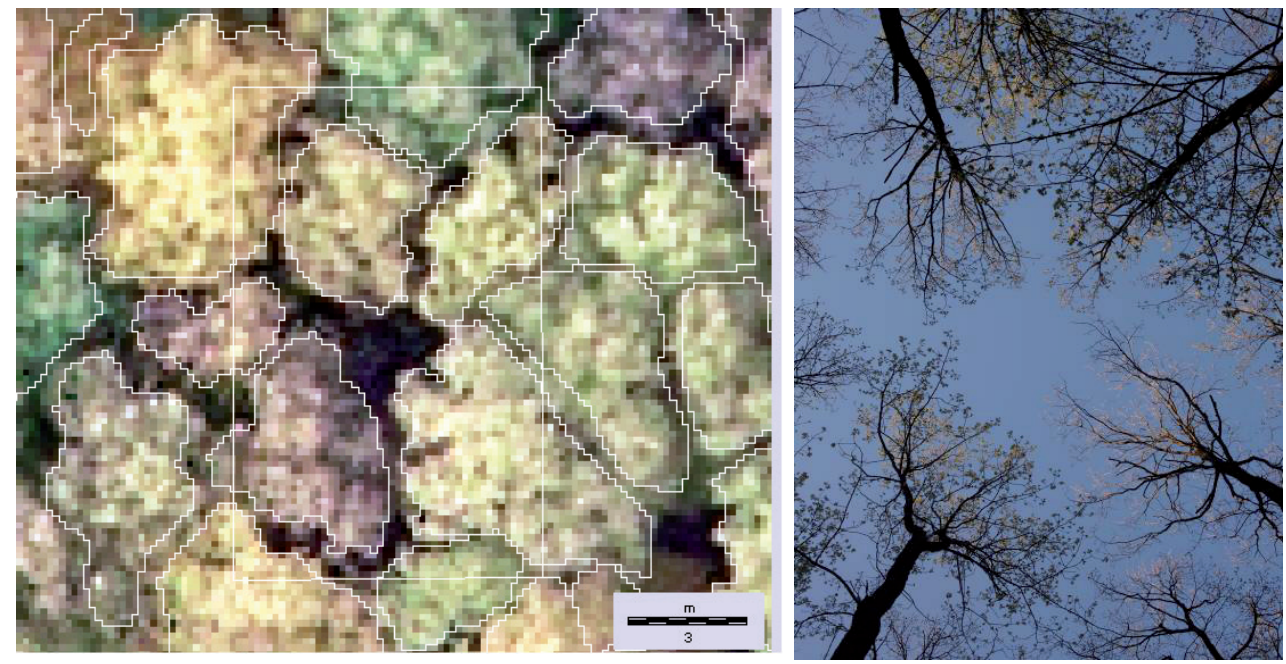

Figure 5 Comparison of crowns pictures captured on aerial and terrestrial images. Terrestrial image were rotated and flipped to fit them with aerial image

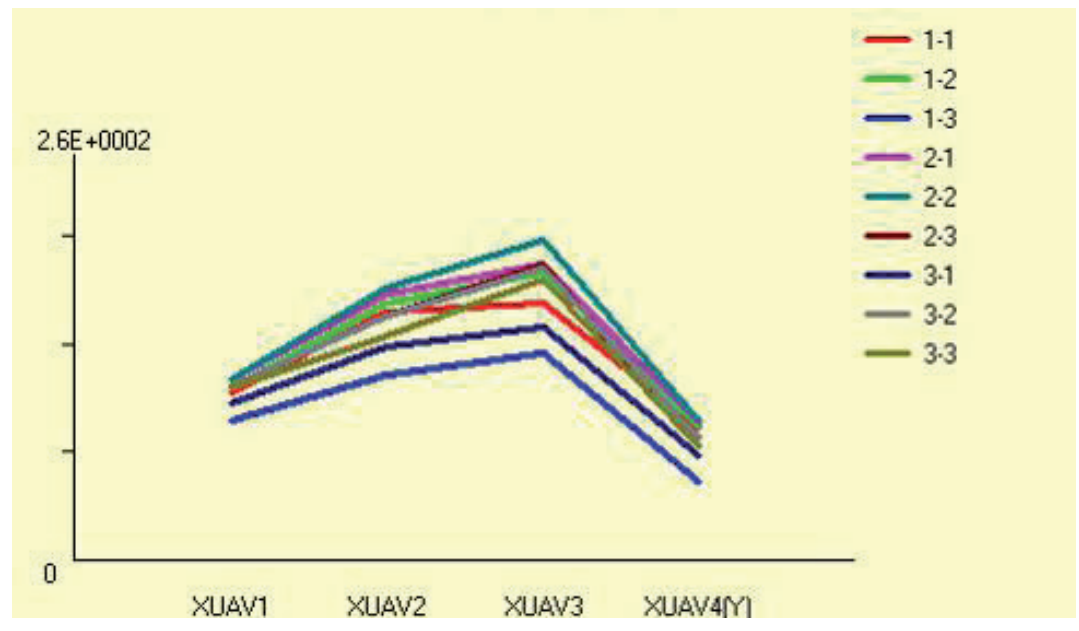

Figure 6. Mean brightness of crowns belonging to nine groups according to classification results of two interpreters in four spectral bands (from left: blue, green, red, infra red)

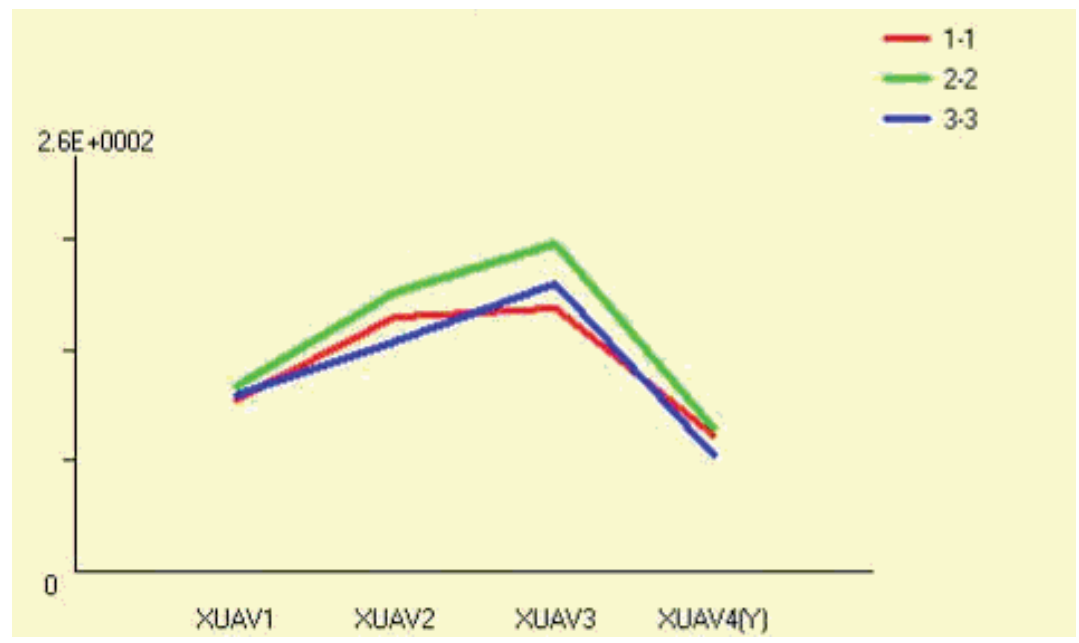

Figure 7. Mean brightness of crowns classified by two interpreters in harmony into three groups - green (1-1), yellow (2-2) and brown (3-3), in four spectral bands (from left: blue, green, red, infra red) 


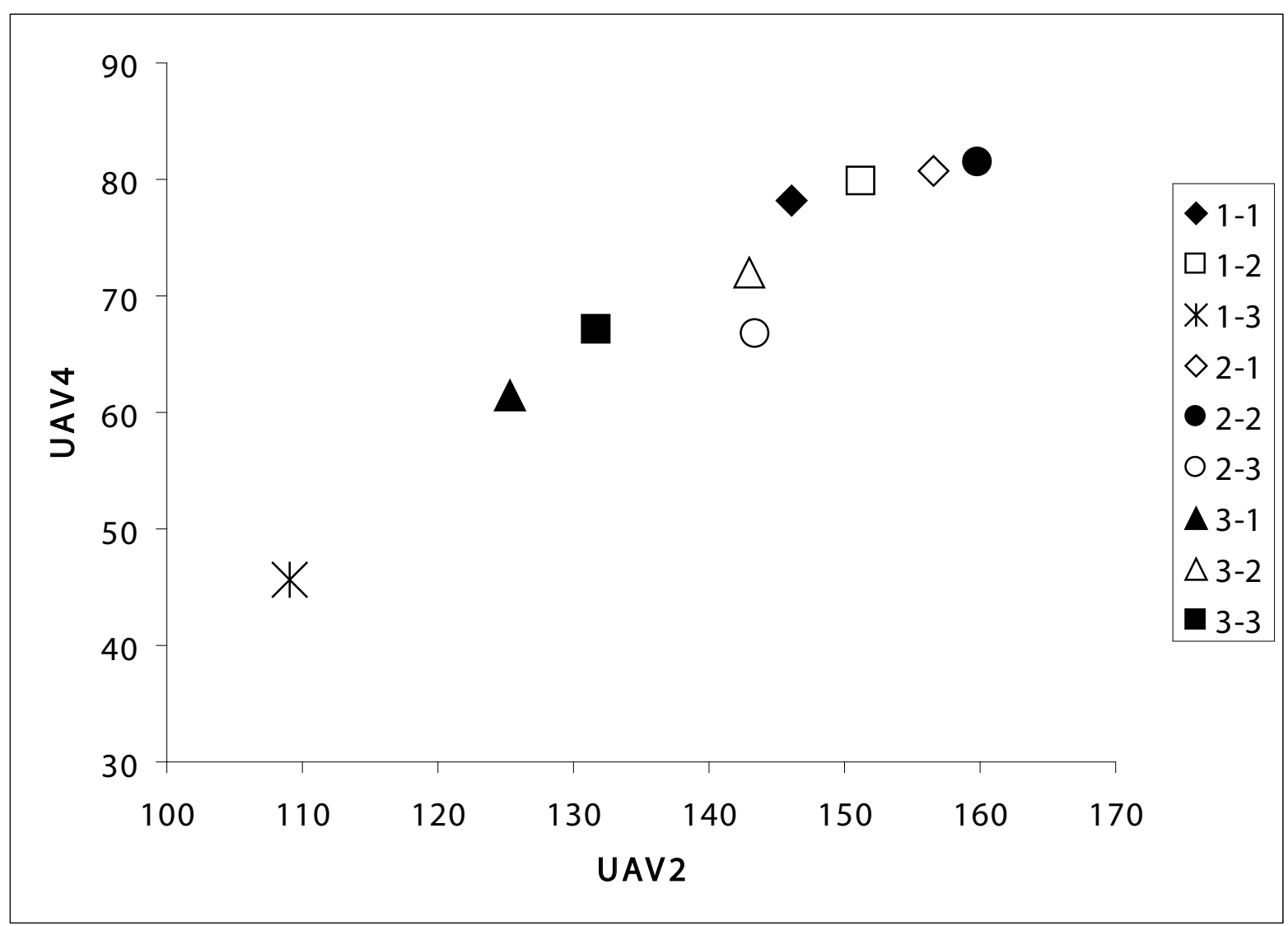

Figure 8. Mean brightness of crowns belonging to nine groups according to classification results of two interpreters in two spectral bands: green (band 2) and infra red (band 4)

\section{Results}

The largest spectral differences between distinguished, by visual classification, crown groups (Fig. 6 and 7), was in the red channel (XUAV3), green (XUAV2) then in blue (XUAV1) and infrared (XUAV4), respectively. Analyzed images are characterized by other interpretive properties, compared to typical multispectral images obtained for full growing season and with professional imaging systems. It has to be kept in mind, that images were acquired in the autumn season.

The percent of trees classified by both observers in harmony to same classes is high $(79.7 \%)$. Although they used various computer systems, obtained results are consistent. This indicates, that images provide a relatively accurate differentiation of trees with different leaf colors. Other trees - those that observers classified in different way - formed a group with colors close to the main classes (Tab. 1, Fig. 8): green-yellow and yellow-green (1-2 and 2-1) or yellow-brown and brownish-yellow (2-3 and 3-2). Radically different crown assignment to color classes, such as $3-1$ or $1-3$, occurs rarely (only $0.5 \%$ of the total number of trees). This was expected due to continuous character of this phenomenon. In the presented study, 3 color classes were used for crown characterization. Maybe in the future more classes, taking into account transient classes, should be added to analysis. This should be preceded by a deeper study of the formation of color composition in the systems of remote sensing and image perception by different observers.

No clear correlation between development phases observed in the autumn aerial and spring terrestrial images was noted. Although the data in tab. 2 suggest the existence of certain trends, such as the fact, that early growing oaks in the spring are dominated by those, in which leafs were brown in the autumn, and that most of the "delayed" oaks were with green and yellow leafs. Other finding is that oaks with green and yellow leaves were more frequently represented, than others, in the class of delaying trees. Oaks with brown leaves were represented in similar proportion in all three classes. However, an attempt was made based on a relatively small sample, so presented conclusions should be approached with caution. 


\section{Conclusions}

Based on the survey it can be stated, that sessile oak autumn phenological stages can be recorded with high reliability at the level of individual tree crowns using images taken by a camera carried by unmanned aerial vehicle. In order to develop an appropriate methodology, it is necessary to undertake a broader study of the perception of this phenomenon by different observers. The results indicate, that it is possible to apply image classification methods both: multispectral (pixel) and the object, in which, the object would be the individual tree crowns.

There is no doubt, that methodology of spring observations has to be improved and the number of observed trees has to increase. Terrestrial images should be taken more frequently and in projections which allow observations of the whole of crowns. Best solution would be using spring images acquired by UAV.

The use of UAV in the creation of maps of phenological changes on the single tree level would provide information about the length of the individual tree growing season length. Such information as map of individual tree growing season length could be utilized by stand or tree growth models. Further work is required to determine the characteristics, that indicate the start or end of the growing season. Integration of both data (terrestrial and airborne) obtained from ground-based measurements of air will allow for full automation of the process.

\section{Acknowledgements}

The study was based on images acquired during the project 505-10-03260052, "Assessment of the pine stands health on the basis of non-metric multispectral digital images obtained with an unmanned aerial vehicle", funded by the Warsaw University of Life Sciences - SGGW in 2011.

\section{References}

Bobinac M., Batos B., Miljković D. \& Radulović S., 2012, Polycyclism and phenological variability in the common oak (Quercus robur L.), Archives of Biological Sciences, Belgrade, 64 (1): 97-105.

Clark A. F., Woods J. C. \& Oechsle O., 2010, A low-cost airborne platform for ecological monitoring. Int. Archives of Photogrammetry, Remote Sensing and Spatial Information Sciences, Vol. XXXVIII, Part 5, Com. V.

Cheak S. F., 2004, Detecting near-UV and near-IR wavelengths with the FOVEON image sensor, Naval Postgraduate School, Monterey, California, USA.

Crawley M. J. \& Akhteruzzaman M., 1988, Individual variation in the phenology of oak trees and its conse- quences for herbivorous insects, Functional Ecology 2 (3): 409-415.

Eisenbeiss, H., Lambers K. \& Sauerbier M., 2005, Photogrammetric recording of the archaeological site of Pinchango Alto (Palpa, Peru) using a mini helicopter (UAV), Int. Archives of Photogrammetry, Remote Sensing and Spatial Information Sciences XXXIV-5/ C34: 238-243.

Greer J. D.; Hoppus M. L. \& Lachowski H. M., 1990, Color infrared photography for resource management - unique attributes improve vegetation mapping and resource management, Journal of Forestry 88 (7): 12-17.

Grenzdörffer G. J, Engelb A. \& Teichert B., 2008, The photogrammetric potential of low-cost UAV's in forestry and agriculture, Int. Archives of the Photogrammetry, Remote Sensing and Spatial Information Sciences, Vol. XXXVII. Part B1.

Gruen A., 2012. First civilian photogrammetric UAV flight over Singapore. www.asmmag.com/201203213420/ first-civilian-photogrammetric-uav-flight-over-singapore.html (29.04.2012).

Idrisi 2009, Idrisi Taiga Manual, Clark Labs, Worcester, USA.

Jankowicz B., 2002a, Zastosowanie niskopułapowych lotów bezzałogowych dla fotogrametrycznego pozyskiwania informacji o terenach wiejskich [The Use of low-altitude flights for photogrammetric acquisition of data regarding arable areas], Archiwum Fotogrametrii Kartografii i Teledetekcji 12a: 145-150.

Jankowicz B., 2002b, Przydatność obrazów rejestrowanych kamerami APS (Advanced Photo System) z nalotów niskopułapowych dla fotogrametrycznego monitoringu obszarów wiejskich [Usability of images taken by APS (Advanced Photo System) cameras for photogrammetric monitoring of arable areas], Archiwum Fotogrametrii Kartografii i Teledetekcji 12a: 151-153.

Jankowicz B., 2007, Analiza zastosowania bezzałogowych fotogrametrycznych nalotów niskopułapowych w kontekście szybkiego pozyskiwania geoinformacji [Analysis of unmanned air low-height photogrammetric flights for quick collection of geoinformation], Archiwum Fotogrametrii Kartografii i Teledetekcji 17a: 329-338.

Jaszczak R., 2000, Charakterystyka wskaźników uszkodzenia koron drzew sosny zwyczajnej (Pinus sylvestris L.) różnych klas biosocjalnych [Description of tree crown damage indices in scots pine (Pinus Sylvestris L.) of different biosocial classes], Sylwan CXLIV No. 9: 65-76.

Jenkins J. P., Braswell B. H., Frokling S. E. \& Aber J. D., 2002, Detecting and predicting spatial and interannual patterns of temperate forest springtime phenology in the eastern U.S., Geophysical Research Letters 29.

Kadomatsu M., 1997, Differences in phenology of Quercus collected from northern China, eastern Hokkaido and 
western Honshu, Research Bulletin of the Hokkaido University Forests 54 (2): 188-201.

Królikowski J., 2011, Latać każdy może [Everybody can fly], Geodeta 7 (194): 48-51.

Kumar V. 2012, Autonomous agile aerial robots, TED Conference., http://www.youtube.com/watch?v=4ErEBkj_3PY\&feature=player_embedded (12.05.2012).

Lechowicz M. J., 1984, Why do temperate deciduous trees leaf out at different times? Adaptation and ecology of forest communities, American Naturalist 124 (6): $821-$ 842.

Miścicki S., 1981, Zależność między przyrostem miąższości a barwą korony sosny na lotniczych zdjęciach spektrostrefowych z rejonu słabych uszkodzeń przemysłowych drzewostanów [Relationship between volume increment and colour of pine crowns on air spectro-zonal photos from the region of weak industrial damege in forests stands], Sylwan 5: 9-19.

Morin X., Roy J., Sonie L. \& Chuine I., 2010, Changes in leaf phenology of three European oak species in response to experimental climate change, New Phytologist 186 (4): 900-910.

Muraoka H. \& Koizumi H., 2009, Satellite Ecology (SATECO) - linking ecology, remote sensing and micrometeorology, from plot to regional scale, for the study of ecosystem structure and function, Journal of Plant Research 122: 3-20.

Oliveira G., Correia O., Martins-Loução M. A. \& Catarino F. M., 1994, Phenological and growth patterns of the Mediterranean oak Quercus suber L., Trees 9: 41-46.

Richardson A. D., Braswell B. H., Hollinger D. Y. \& Jenkins J. P., Ollinger S. V., 2009, Near-surface remote sensing of spatial and temporal variation in canopy phenology, Ecological Applications 19: 1417-1428.

Sass-Klaassen U., Sabajo C. R. \& den Ouden J., 2011, Vessel formation in relation to leaf phenology in pe- dunculate oak and european ash, Dendrochronologia 29: $171-175$.

Schwartz M. D., 1998, Green-wave phenology, Nature 394: 839-840.

Seiwa K., 1999, Changes in leaf phenology are dependent on tree height in Acer mono, a deciduous broad-leaved tree, Annals of Botany 83: 355-361.

Stone Ch. \& Haywood A., 2006, Assessing canopy health of native eucalypt forests, Ecological Management \& Restoration 7: 24-30.

Taxus, 2010, Taxus SI Sp. z o.o. Samolot do fotografii z powietrza, Dokumentacja techniczna [An airplane for aerial photography. Technical data], Warszawa.

Waddell K. J., Fox C. W., White K. D. \& Mousseau T. A., 2001, Leaf abscission phenology of a scrub oak: consequences for growth and survivorship of a leaf mining beetle, Oecologia 127: 251-258.

Wesołowski A. \& Rowiński P., 2006, Timing of bud burst and tree-leaf development in a multispecies temperate forest, Forest Ecology and Management 237: 387-393.

Zmarz A., 2011, Zastosowanie bezzałogowych statków latających do pozyskania danych obrazowych o lesie [Applying unmanned aerial vehicles for obtaining forests' image data], Dep. of Forest Management, Geomatics and Economics, Warsaw University of Life Sciences - SGGW, Warsaw (PhD thesis).

Zmarz A., Będkowski K., Miścicki S., Plutecki W., 2012, Ocena stanu zdrowotnego świerka na podstawie analizy zdjęć wielospektralnych wykonanych fotograficznymi aparatami cyfrowymi przenoszonymi przez bezzałogowy statek latający [Assesment of norway spruce health using multispectral images acquired from unmanned aerial vehicle with non-metric cameras], Archiwum Fotogrametrii, Kartografii i Teledetekcji 23: 541-550. 
